\title{
Physiological ecology of crabs from Saudi Arabian mangrove
}

\author{
A. A. Eshky ${ }^{1}$, R. J. A. Atkinson ${ }^{2}$, A. C. Taylor ${ }^{3, *}$ \\ ${ }^{1}$ Faculty of Marine Science, King Abdulaziz University, PO Box 1540, Jeddah, Saudi Arabia \\ ${ }^{2}$ University Marine Biological Station, Millport, Isle of Cumbrae KA28 OEG, Scotland, UK \\ ${ }^{3}$ Division of Environmental \& Evolutionary Biology, Institute of Biomedical \& Life Sciences, University of Glasgow, \\ Glasgow G12 8QQ, Scotland, UK
}

\begin{abstract}
This paper presents the results of field studies on the physiology, ecology and behaviour of 2 species of crab from Avicennia marina mangrove near Jeddah, Saudi Arabia. One crab, the ocypodid Uca inversa inversa, occurs at the top of the eulittoral zone where it constructs burrows. Measurements of microclimate show that these burrows provide essential protection from environmental extremes. Burrow temperatures (air and sediment) were consistently lower and less variable than sediment surface temperatures or air temperatures just above the sediment. Crab body temperature closely followed burrow temperature. When out of the burrow, evaporative cooling maintained body temperature lower than that of the surrounding air. The relative humidity of burrow air was consistently higher than that outside and the burrows provided a necessary source of standing water. Crab heart rate was monitored in order to assess physiological stress. The grapsid Metopograpsus messor occurs throughout the mangrove and makes strategic use of the mangrove vegetation in order to minimize the effects of thermal stress, though some crabs opportunistically utilize burrows. M. messor appears to be more vulnerable to thermal stress than $U$. inversa.
\end{abstract}

KEY WORDS: Crabs Uca Metopograpsus Physiology Ecology Behaviour Burrowing $\cdot$ Mangrove

\section{INTRODUCTION}

The littoral environments of the Red Sea are characterized by wide diel temperature fluctuations (Morley 1975, Eshky 1985j. Depending on the time of day and the time of year, environmental temperatures may rise above the upper lethal limits of the littoral fauna; it seems unlikely that their lower lethal limits are ever reached. Crabs are conspicuous members of mangrove ecosystems (mangal) throughout the tropics (Verwey 1930. Macnae 1968) and, in the case of the mangrove areas visited, there are 2 species which, by behavioural and physiological means, were found to be able to survive extreme environmental conditions. These are the ocypodid crab Uca (Amphiuca) inversa inversa (Hoffmann) and the grapsid crab Metopograpsus messor (Forskål). Uca inversa and $M$. messor are both

•E-mail: gbza37@udcf.gla.ac.uk semiterrestriali $U$. inversa is common in Red Sea mangrove areas and occupies burrows in the upper eulittoral zone (Edney 1961, Crane 1975, Lewinsohn 1977. Vannini \& Valmori 1981b, Sheppard et al. 1992), whereas $M$. messor shelters amongst the mangrove trees (Avicennia marina). M. messor is a widely distributed eulittoral species (Barnard 1950, Banerjee 1960, Forest \& Guinot 1961, Crosnier 1965) which characteristically occurs on rocky shores, but also in other shore environments such as mangrove areas (Fishelson 1971, Hartnoll 1975, Jones et al. 1987, Vannini \& Valmori 1981a, Sheppard et al. 1992). At appropriate times of day, both species emerge from refuges to forage, but each employs a different feeding strategy.

Red Sea mangal is often poorly developed (Jones et al. 1987, Sheppard et al. 1992) and Jones et al. (1987) noted a progressive impoverishment of the mangrove fauna towards the north of the Red Sea. The mangrove plants at the study sites consisted of bush-like growths of Avicennia marina which rarely exceeded $3 \mathrm{~m}$ in height. 
In this paper, the behaviour and physiology of $U_{C a}$ inversa and Metopograpsus messor were examined with particular reference to environmental temperature changes.

\section{METHODS}

Most field work was carried out at an essentially island site at Ras Hatiba, immediately NW of Dah'ban, Saudi Arabia. During summer, a narrow causeway linked the study area to the mainland, but for much of the year this causeway was inundated. Human disturbance was minimal and there were large populations of both crab species. The most comprehensive series of experiments was conducted over complete $24 \mathrm{~h}$ periods. Thermocouples (RS Components) were used to monitor temperature changes in various microhabitats occupied by the crabs and were also used to record crab body temperature. In the latter case, a thermocouple was inserted through a small hole drilled in the carapace dorsal to the hepatopancreas. Thermocouples were attached to a battery-powered meter via a selector switch (RS Components). The physiological condition of selected crabs was assessed by measuring heart rate using impedance electrodes (Hoggarth \& Trueman 1967, Taylor 1976) connected to an oscillographic recorder (Searle Bioscience). Relative humidity in crab microhabitats was monitored using a portable digital psychrometer (Theis Clima). The behaviour of crabs was also continuously assessed and related to environmental changes (diel and tidal). In the case of $U_{C a}$ inversa, further microclimate information, including $24 \mathrm{~h}$ of recordings, was obtained from crab habitats near Gettlah on the Farasan Islands in the southern Red Sea. Limited observations were also made at Midaya, near Jizan (southern Red Sea).

Some burrows of Uca inversa were cast with polyester resin in order to determine their structure. Measurements were taken to investigate relationships between crab size and burrow size, and between burrow depth and position on the shore.

Laboratory experimentation was carried out at the Obhur Marine Station of the Faculty of Marine Science, King Abdulaziz University, Jeddah, Saudi Arabia. Here, a simulated natural environment in a large, circular ( 2 m diameter) outdoor tank enabled further experiments on the effects of temperature on crabs to take place. Tanks contained $40 \mathrm{~cm}$ depth of sediment from Uca inversa habitat; a water table was present $30 \mathrm{~cm}$ below the sediment surface. The $U$. inversa used in these experiments were obtained from Ras Hatiba and from Midaya where crabs were more abundant (over 30 crabs $\mathrm{m}^{-2}$ in some areas) than at Ras Hatiba and a larger size range was available. These crabs readily constructed burrows in the sediment of the laboratory tank. The creation of areas of shade and shallow pools of standing water also enabled the tank to be used for experiments with Metopograpsus messor on other occasions.

The main periods of field investigation were in July 1987 (Midaya), October and December 1987 (Ras Hatiba), and January (Farasan Islands), March (Ras Hatiba) and July 1989 (Farasan Islands). Laboratory work on respirometry and blood chemistry also took place, both at King Abdulaziz University and at Glasgow University, Scotland, UK, from 1987 to 1991, but the results of this work will be reported elsewhere.

\section{RESULTS}

\section{Distribution and behaviour}

\section{Uca inversa}

At Ras Hatiba, the burrows of Uca inversa occurred in a broad zone from the top of the eulittoral close to terrestrial halophytic shrub vegetation to amongst $A v i$ cennia marina in the mid-eulittoral zone. No other Uca species was present at the site. In October 1987, 2 areas, each of $1 \mathrm{~m}^{2}$, were carefully observed at hourly intervals. Each contained a number of $U$. inversa burrows; one was near the top of the $U$. inversa zone, the other was lower down the shore in the mangrove. No crabs were seen in the lower quadrat and there was absolutely no sign of any new feeding pellets or of newly excavated sediment. In contrast, the upper shore quadrat showed signs of both and crabs were seen emerging from several of the burrows within the quadrat. This implies either that the midshore crabs do not emerge during neap tide cycles, or that the burrows in this zone are vacated burrows that were occupied either during the previous spring tide cycle or earlier in the year when the mean sea level was lower. Burrow longevity is unknown at present.

In the upper shore zone the burrows were often occupied, and here counts of burrows in each $\mathrm{m}^{2}$ along a $30 \mathrm{~m}$ transect indicated a burrow density of $8.8 \mathrm{~m}^{-2}$ (SD 5.6). Burrow occupancy along the transect was not determined. Within the $1 \mathrm{~m}^{2}$ upper shore sample quadrat, however, only 4 out of 13 burrows appeared to be occupied. Towards the lower edge of the Uca inversa zone, a lateral $30 \mathrm{~m}^{2}$ transect gave a burrow density of $2.7 \mathrm{~m}^{-2}$ (SD 2.3). No $U$. inversa were seen in this area (see above), so burrow occupancy is unknown; the absence of tracks, feeding pellets, or signs of fresh excavation and burrow plugging suggested that few, if any, of these burrows were occupied at the time of observation. 
The behaviour of Uca inversa was influenced by both tidal and diel environmental variables. One $24 \mathrm{~h}$ experiment commenced at $12: 30$ h on 1 October 1987. with full data collection from 15:30 h until 14:30 h the following day. Recordings and observations were made at hourly intervals, at 30 min past each hour. Sunset occurred at just before the 18:30 h observations and sunrise just after the 05:30 h observations, so that at these times observations took place in twilight. The tide was a neap tide (moon in last quarter), but appeared to be influenced by the southwesterly wind. The study site was on the eastern side of the island. Measurements indicated that high water occurred at around $16: 30 \mathrm{~h}$ and $04: 30 \mathrm{~h}$, low water at around 23:30 $\mathrm{h}$ and 12:30 h. This asymmetry was because wind effects masked the tidal effects (the total rise and fall was just $62 \mathrm{~mm}$ ). The top of the $U$. inversa zone was never covered by these tides and here the depth of the water table varied from 32.0 to $25.8 \mathrm{~cm}$ beneath the plane of the sediment surface. The lower part of the zone under investigation was just covered by water at high tide. The water table in these burrows was, therefore, only some $6 \mathrm{~cm}$ below the sediment surface at low tide during the period of observation, whereas it was around $30 \mathrm{~cm}$ below sediment surface at this time in the upper part of the zone. Most of the zone under observation was not covered by the rising tide, though the lower sections of burrows were inundated by rising ground water.

Throughout the afternoon and night, the crabs remained within their burrows (except for a single specimen that was seen on the mud surface at 15:30 h). Emergence occurred in the morning, after several hours of daylight. For the crabs in the lower part of the zone under observation, this corresponded with the time when their burrow openings were exposed to aerial conditions by the receding tide. However, the crabs higher on the shore did not appear to emerge earlier so there may be an environmental temperature effect. Control of emergence is likely to be endogenous (see Lehmann 1976, Webb 1983). Emergent crabs were initially inactive at their burrow openings. Some removed plugs of sediment in order to emerge, but most burrows were not plugged. Soon, deposit feeding commenced with male crabs also making small-amplitude waving movements with the folded major cheliped. Male crabs appeared to emerge from their burrows before the females; the first male crab was seen at $07: 15 \mathrm{~h}$, whereas the first female was not seen until 07:50 h. At 09:30 h, many crabs were feeding. The mean feeding rate observed for 4 male crabs was 96 small cheliped movements $\min ^{-1}$ while that observed for a female was $102 \mathrm{~min}^{-1}$ (both chelipeds used). Feeding activity continued throughout the period of emergence, but periodically crabs would return to their burrows. The fre- quency of this activity was not noted, but it is a wellknown behaviour pattern described for other Uca species (Wilkens \& Fingerman 1965, Macintosh 1978). This burrow retreat behaviour is probably primarily related to the need for water replenishment, but will also have the effect of reducing body temperature (Macintosh 1978, Atkinson \& Taylor 1988)

At around 10:30 h a change in crab behaviour was noted. Male crabs were seen to be engaged primarily in display. This involved an erect stance, with the extended walking legs lifting the body well clear of the substratum, and waving movements of the major cheliped. In several cases, males attempted to attract the attention of specific female crabs. The closest encounters involved male and female crabs orientated backto-back whilst making lateral movements. No successful courtship encounters were observed; the females all eventually retreated to their own burrows without further activity by the males. Occasionally, males disputed over territory, burrow occupancy or the attention of females. It is likely that peak courtship behaviour will be during periods of spring tide as in many other Uca species (Zucker 1983).

At $12: 30 \mathrm{~h}$, the number of crabs active on the mud surface had decreased from around 20 to 6 in the ca $10 \mathrm{~m}^{2}$ area most closely studied, and the activity level of those remaining was also less than it was previously. Crabs were still engaged in display and feeding, interspersed with periods of inactivity in their burrow openings. Some digging activity was observed, both sediment removal from the burrow and plug construction, though most crabs observed made no attempts to do either. At 13:30 h, only 1 crab (a male) remained on the sediment surface at its burrow opening. Several minutes later it withdrew into its burrow and no more surface activity was observed. The rising tide reached the lower part of the zone under observation at 14:30 h.

These results are shown in summary form in Fig. 1.

The physiological recordings that accompanied these observations are given together with measurements of environmental variables in a subsequent section (see Figs. 3A, 5 \& 8A).

Burrows of Uca inversa are illustrated in Fig, 2(a to i). The main orientation of the burrows was vertical. The burrows of male crabs had a loose spiral configuration, whereas those of the females had no spiral component. This appeared to relate to the fact that, in males, only the limbs on the minor cheliped side were employed in excavation and sediment removal. Of 24 burrows cast with polyester resin and examined in detail (16 occupied by male, 8 occupied by female crabs), 4 (2 occupied by male, 2 by female crabs) were Y-shaped with 2 shafts to the surface (Fig. 2b, where 1 opening was closed at the time of casting, and Fig. 2 d). The remaining burrows had only 1 shaft and therefore a single 


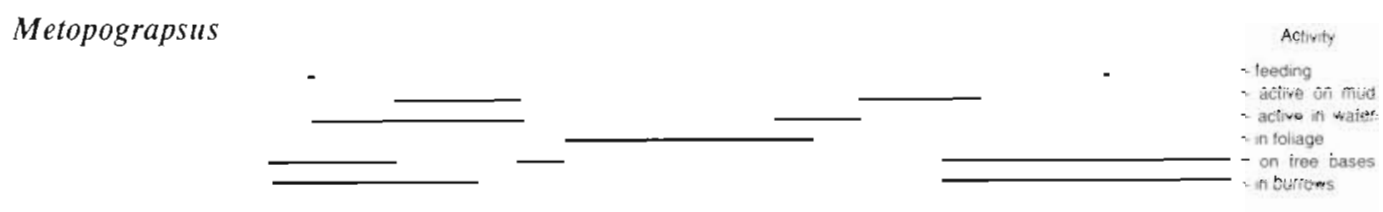

Uca
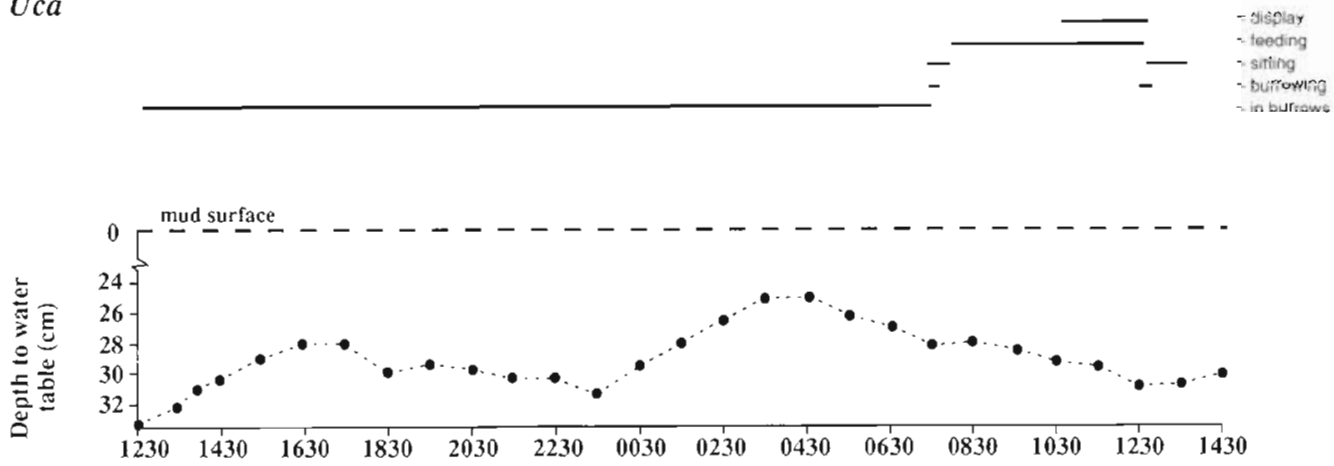

Time

Fig. 1 Uca inversa and Metopograpsus messor. Summary of observed activities of crabs on 1-2 October 1987 at the Ras Hatiba study site. Tidally modulated changes in water table depth were monitored in the upper part of the $U$. inversa zone

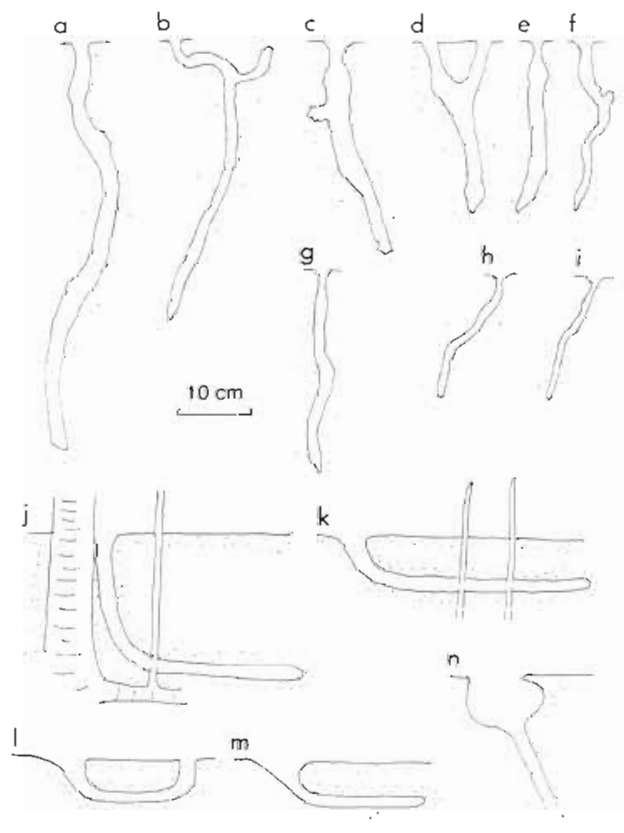

Fig. 2. Diagrams of the burrows occupied by Uca inversa (a to i) and Metopograpsus messor (j to $n$ ). Drawings of the burrows of $U$. inversa have been accurately derived from photographs of resin casts whereas those of $M$. messor are diagrammatic, based on fleld measurements. For $U$. inversa, at the time of casting, burrows (a), (c), (d), (e) and (g) were occupied by male crabs, burrows (b). (f), (h) and (i) by female crabs. For $M$. messor, burrow (j) is against the trunk of Avicennia marina and both (j) and $(\mathrm{k})$ are intersected by pneumatophores opening. For these 24 burrows, significant correlations were found between burrow width and crab size $(\mathrm{p}<$ 0.001 ), and between burrow depth and the position on the shore $(\mathrm{p}<0.001)$; burrows higher on the shore were deeper, reflecting the necessity to reach the water table. These burrows and all other burrows excavated when collecting crabs for experiments contained standing water. The mean maximum burrow depth was $29.2 \mathrm{~cm}$ (SD 9.8, $\mathrm{n}=24$ ). A feature not represented in the burrows cast, but often seen in the burrows of large male crabs, was that the terminal section of the burrow curved to become horizontal and, in some cases, curved back towards the surface for a short distance. This section was sometimes slightly wider than the rest of the burrow. The burrows of female crabs were vertical or near-vertical shafts (deviations from the vertical were often to negotiate obstructions and were often slightly dilated at the base

Mud excavated from the burrows was deposited near the openings and, in some cases, at the top of the shore at Ras Hatiba, was used to construct a low rim around the burrow or was piled up at one side of the burrow opening (usually the landward side). Uca species are known to construct a variety of structures at their burrow openings (Zucker 1974, Crane 1975), but these were not prominent for the $U$. inversa observed. 


\section{Metopograpsus messor}

This species was common in the mangrove at Ras Hatiba. Crabs were observed throughout the Avicennia marina zone, but unlike Uca inversa, they did not occur beyond its inland margin. On 1-2 October 1987. crab behaviour was observed along a $50 \mathrm{~m}$ transect parallel to the shoreline at the high tide mark and along a $50 \mathrm{~m}$ transect that traversed the shore, down to the approximate position reached by the low tide.

The behaviour of this species (see Fig. 1) was quite different from that of Uca inversa since most specimens did not withdraw into burrows, but utilized the shade provided by the Avicennia marina plants during the warmest hours of the day. Some crabs, however, were seen to be active during all daytime observation periods, and their activity was probably related to foraging and occurred mostly in the shade of the mangrove. Detailed observations of feeding were made only on 2 occasions. During the first, at $16: 30 \mathrm{~h}$, crabs were seen to be rapidly conveying small particulate material from the sediment surface to their mouthparts, using their chelipeds. This material was probably derived from the mangrove plants since it is well known that various components of mangrove litter are consumed by crabs (Micheli et al. 1991). The second feeding observation was at $11: 45 \mathrm{~h}$, when a crab was seen to attack a male $U$. inversa. The grapsid seized the male's major cheliped, which was then shed and carried away by the grapsid.

During the cooler hours of the day, Metopograpsus messor were seen moving across the mud plain amongst the Avicennia marina pneumatophores. This activity occurred both in shallow water when the crabs were either totally immersed or partially immersed, and when the crabs were exposed to the air by the ebb tide. The largest numbers of crabs were seen in conditions of aerial exposure and movements into water were often in response to human disturbance. As the temperature increased, crab activity decreased and most crabs moved into the shelter of the A. marina. At low tide, crabs remained around the bases of the trees and, as the tide flooded, they climbed up the trunks of the trees to remain just above the surface of the water. During the warmest part of the day, the water temperature over the mud flat reached $38.5^{\circ} \mathrm{C}$. The air temperature in the shade did not exceed $34.6^{\circ} \mathrm{C}$ and relative humidity was always greater than $60.8 \%$. An alternative strategy for some crabs was to occupy burrows. Some of these burrows were modified Uca inversa burrows (e.g. Fig. 2n), but many were of shallow construction and were apparently made by $M$. messor. This is supported by an observation of 1 specimen of $M$. messor removing sediment from a shallow burrow. Examples of these burrows are given in
Fig. $2(\mathrm{j}$ to $\mathrm{m})$. It is possible that some of these burrows may have been the modified burrows of Macrophthalmus spp., but investigation failed to reveal any of these crabs at the site. $M$. messor were seen to occupy burrows whose openings were both immersed and emersed, but most were in the latter category.

Nocturnal observations were particularly interesting. During the part of the night when the flood tide covered the mud flat, Metopograpsus messor were seen to climb high into the Avicennia marina. Some were seen clinging to foliage in the upper half of the trees, while many clung to the main branches close to where they diverged from the trunk. These crabs appeared to be inactive. Others climbed above the water by bracing themselves between adjacent $A$. marina pneumatophores, the walking legs on one side clinging to one pneumatophore and those on the other side clinging to another. It may be significant that the water temperature dropped to $26.0^{\circ} \mathrm{C}$ during the night. The minimum air temperature was $27.4^{\circ} \mathrm{C}$ and the minimum relative humidity in the $A$. marina foliage was $86 \%$. Crabs descended from the trees just before sunrise which also coincided with the ebbing tide. It seems likely that the crabs avoid both high and low temperature extremes. Changes in physical environmental conditions during the $24 \mathrm{~h}$ cycle are shown in Figs. 3 \& 5. Heart rate and body temperature were not measured for this species on this occasion.

Further field observations were made from 11:30 to 21:30 h on 23 March 1989 at the same site. On this occasion, microclimatic data were collected around one of the largest mangrove trees near the top of the shore and the body temperatures of 2 crabs were monitored (see below). At the same time the behaviour of the small number of crabs occurring around this tree was noted. Only 4 crabs were noted at $13: 30 \mathrm{~h}$ and these were all in the shade at the base of the trunk. At 15:30 h, 6 crabs were present in this region, some of which were making excursions on the mud surface. Thereafter, the numbers of crabs observed at hourly intervals fluctuated at between 4 and 8 crabs. Observations suggested that the variation in numbers reflected local immigration and emigration rather than emergence from cryptic locations which had been overlooked previously. Observations also indicated that as environmental temperatures declined, crabs became more active and moved over the sediment plain, resting in areas of shade, and that such ambulatory activity was greatest during darkness. As in the October observations, crabs appeared to avoid prolonged immersion, and at 21:30 h, when the tide reached the site, 1 crab was seen to climb up pneumatophores and others ascended the trunk of the tree to remain above the water level. 


\section{Environmental variables}

\section{Uca inversa habitat}

Diel variations in temperature are shown in Fig. 3. Fig. 3A illustrates data obtained at Ras Hatiba on 1-2 Oct 1987; Fig. 3B illustrates data obtained at the Farasan Island site on 17-18 January 1989. Fig. 3A, B illustrates the close correspondence between $c r a b$ body temperature and temperature within the burrow. In each case, this latter temperature was measured by a thermocouple cemented to the crab and positioned to measure temperature ca $2 \mathrm{~mm}$ above the carapace. This will be either air temperature or sediment temperature (when the dorsal carapace is in contact with the burrow wall); burrow air temperature is similar to the temperature of the surrounding sediment (see Table 2). Wired crabs did not emerge from their burrows $(7$ male crabs were used in these experiments; all
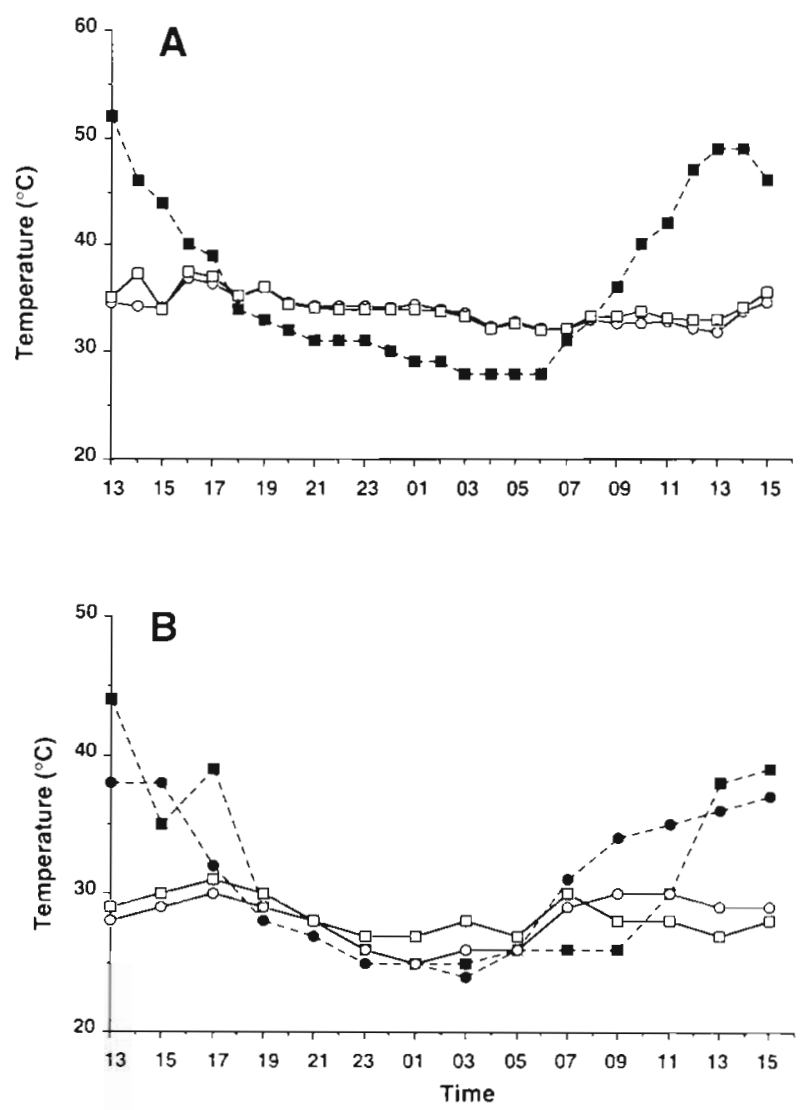

Fig. 3. Uca inversa. Diel variations in environmental temperature and crab body temperature at the (A) Ras Hatiba and (B) Farasan Island study sites. Temperature recordings are of sediment surface (a), air close (ca $2 \mathrm{~cm}$ ) to the sediment surface (๑), air in close proximity to the crab (see text) (a), and crab body temperature (o). Recordings were made during 1-2 October 1987 and $17-18$ January 1989 at the Ras Hatıba and Farasan Island sites, respectively behaved similarly\}. The temperature at the sediment surface during this period showed marked diel variation. At Ras Hatiba, it reached $52^{\circ} \mathrm{C}$ during the day and dropped to $28^{\circ} \mathrm{C}$ at night, a variation of $24^{\circ} \mathrm{C}$. Corresponding values at the Farasan site were 44 and $25^{\circ} \mathrm{C}$, a variation of $19^{\circ} \mathrm{C}$. Air temperature close to the sediment at Farasan reached $37^{\circ} \mathrm{C}$ during the day and dropped to $23^{\circ} \mathrm{C}$ at night. A complete set of corresponding data is missing from Ras Hatiba because of a malfunctioning thermocouple, but such data as exist indicate that air temperatures above the sediment surface reached at least $36^{\circ} \mathrm{C}$ during the day and dropped to $27^{\circ} \mathrm{C}$ and possibly less during the night. These marked diel cycles contrast with much less variable conditions experienced by the crabs within their burrows.

Another series of temperature measurements was taken at the same site on 9-10 December 1987. On this occasion the diel variation in air temperature above the sediment surface was $11^{\circ} \mathrm{C}$ and the maximum temperature was only $31^{\circ} \mathrm{C}$. Mud surface temperature reached $42^{\circ} \mathrm{C}$. Crab body temperatures were more variable $(18.0$ to $28.1,18.0$ to $29.5,18.0$ to $29.0,22.1$ to $27.0^{\circ} \mathrm{C}$ ) than in the October and January observations illustrated in Fig. 3. A thermocouple at a depth of ca $30 \mathrm{~cm}$ depth within a burrow revealed a diel variation of only $5^{\circ} \mathrm{C}$, which suggests that the 3 crabs which showed larger diel variations than this remained mostly in the upper parts of their burrows where temperature variations were greater (see Tables 1. \& 3). Their degree of movement was probably restricted by the thermocouple and impedance wires attached to them.

Temperature profiles were taken through the sediment on 2 October 1987 at $06: 30$ and at 12:30 h (Fig. 4).

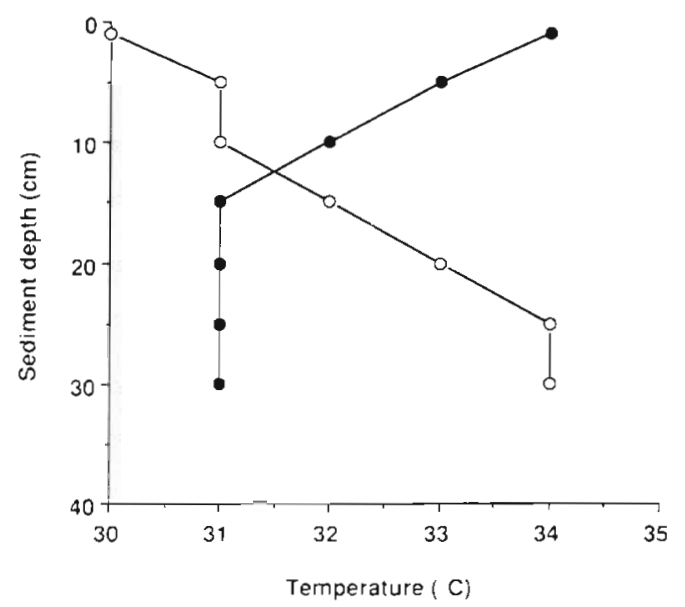

Fig. 4. Temperature profiles taken through the beach sediment at Ras Hatiba at 06:30 h (o) and 12:30 h (•) on 2 October 1987 
The location was just beyond the landward edge of the mangrove amongst the burrows of Uca inversa, i.e. at the top of the zone occupied by these crabs.

At 06:30 h the tidally varying water table was $27 \mathrm{~cm}$ below the sediment surface; at 12:30 h the water table was at $30 \mathrm{~cm}$ below the sediment surface. Note that the highest deep burrow temperatures occurred at 06:30 h. The situation at 12:30 h was the inverse of this.

Another series of measurements was carried out at $2 \mathrm{~h}$ intervals from 12:00 to 10:00 h on 23 March 1989. These are shown in Table 1. These data indicate that the sediment acts as a heat reservoir and that the heat maxima at depth occur many hours after those at the sediment surface. Similar effects have been reported by Powers \& Cole (1976). Air temperatures within burrows will closely follow those of the sediment (Eshky 1985). This was seen in measurements taken at both the Farasan Island site and at Ras Hatiba, and explains the diel variation in burrow air temperature profiles seen in Fig. 4. The Ras Hatiba data, obtained on 6 October 1987, are given in Table 2.

Mud surface temperature was $36^{\circ} \mathrm{C}$, air temperature $30 \mathrm{~cm}$ above the sediment surface was $32^{\circ} \mathrm{C}$, relative humidity $30 \mathrm{~cm}$ above the sediment surface varied between 67 and $71 \%$ and relative humidity $20 \mathrm{~cm}$ within the burrow was $79 \%$. These data were determined in the late morning when the high sun appeared to be responsible for slight heating in the upper part of the Uca inversa burrow.

The data in Table 3 were obtained at the same site on 23 March 1987. From these data it is clear that air temperature variations in the burrow may be the inverse of those in the outside air, particularly in the deeper parts of the burrow. Here, temperatures appear to be determined by the temperature of the surrounding sediment. The burrow is therefore cooler by day and warmer by night than conditions outside.

Table 1. Temperature profiles taken through the beach sediment at Ras Hatiba on 23 March 1989. Maximum temperature in the sediment column at each recording interval is emphasized in bold type

\begin{tabular}{|lcccccc|}
\hline \multirow{2}{*}{$\begin{array}{l}\text { Depth in sedi- } \\
\text { ment }(\mathrm{cm})\end{array}$} & \multicolumn{6}{c|}{ Sediment temperature $\left({ }^{\circ} \mathrm{C}\right)$ at given times } \\
\hline 0 & $12: 00 \mathrm{~h}$ & $14: 00 \mathrm{~h}$ & $16: 00 \mathrm{~h}$ & $18: 00 \mathrm{~h}$ & $20: 00 \mathrm{~h}$ & $22: 00 \mathrm{~h}$ \\
1 & 35 & 39 & 35 & 29 & 24 & 25 \\
5 & 33 & 37 & 38 & 32 & 25 & 24 \\
10 & 28 & 29 & 34 & 33 & 28 & 26 \\
15 & 25 & 24 & 28 & 29 & 29 & 27 \\
20 & 21 & 21 & 25 & 27 & 28 & 27 \\
30 & 20 & 20 & 24 & 25 & 27 & 27 \\
40 & - & - & 22 & 24 & 25 & 26 \\
45 & - & - & 22 & 23 & 24 & 25 \\
& - & - & 22 & 23 & 24 & 25 \\
\hline
\end{tabular}

Table 2. Uca inversa. Beach sediment and burrow air temperature profiles taken at Ras Hatiba on 6 October 1987

\begin{tabular}{|ccc|}
\hline $\begin{array}{c}\text { Depth in sedi- } \\
\text { ment }(\mathrm{cm})\end{array}$ & Mud temp. $\left({ }^{\circ} \mathrm{C}\right)$ & $\begin{array}{c}\text { Burrow air } \\
\text { temp. }\left({ }^{\circ} \mathrm{C}\right)\end{array}$ \\
\hline 1 & 33 & - \\
5 & 31 & 34 \\
10 & 30 & 32 \\
15 & 30 & 32 \\
20 & 30 & 32 \\
25 & 30 & 31 \\
30 & 30 & 30 \\
\hline
\end{tabular}

Limited data were obtained at Midaya on 6-7 July 1987 and at the Farasan Island site on 20 July 1989. The Farasan data indicated that the air temperature at and around an opening of the burrow of $U_{C a}$ inversa declined from $40^{\circ} \mathrm{C}$ at $15: 00 \mathrm{~h}$ to $35^{\circ} \mathrm{C}$ at 19:00 h; corresponding sediment surface temperatures declined from 50 to $38^{\circ} \mathrm{C}$. Throughout this period the air temperature at $20 \mathrm{~cm}$ depth within a burrow was around $5^{\circ} \mathrm{C}$ lower than at the opening, but deeper measurements were not taken. At Midaya in July there was a $21.8^{\circ} \mathrm{C}$ diel variation in sediment surface temperature $\left(52.4\right.$ to $\left.30.6^{\circ} \mathrm{C}\right)$ and burrow temperatures were consistently lower and less variable $\left(24\right.$ to $31^{\circ} \mathrm{C}$ ) than sediment surface temperatures or air temperatures just above the sediment (30 to $44^{\circ} \mathrm{C}$ ).

Despite the fact that the data set is not extensive, it is clear that, in summer, daytime surface temperatures may exceed the upper lethal limits of the crabs $\left(43.4^{\circ} \mathrm{C}\right.$ according to Edney 1961 , between 40 and $45^{\circ} \mathrm{C}$ according to our data) and that the burrow provides essential protection. Our upper thermal limit data are limited in extent. In one experiment in saturated air, involving a total of $50 \mathrm{crabs}$, the $\mathrm{LD}_{50}(50 \%$ lethal dose) at $39,40,41,42$ and $43^{\circ} \mathrm{C}$ were at around $240,30,20,6$ and $2 \mathrm{~min}$, respectively. In another experiment, in which the effect of temperature on heart rate was investigated, heart rates were recorded from several large crabs for several minutes at $45^{\circ} \mathrm{C}$ before their death at such a high temperature. Limited survival at such high temperatures has been shown for some other Uca species (Vernberg \& Tashian 1959).

Relative humidity (RH) values were higher during the night than during the day. Fig. 5 illustrates data from Ras Hatiba on 1-2 Oct 1987; similar data were obtained from the same site in December 1987 and from the Farasan site in January 

23 March 1987 Temperatures were recorded at various depths within burrows at 2 h intervals

\begin{tabular}{|c|c|c|c|c|c|c|}
\hline \multirow{2}{*}{$\begin{array}{l}\text { Depth in } \\
\text { burrow }(\mathrm{cm})\end{array}$} & \multicolumn{6}{|c|}{ Air temperature $\left({ }^{\circ} \mathrm{C}\right)$ at given tumes } \\
\hline & $12: 00 \mathrm{~h}$ & $14: 00 \mathrm{~h}$ & $16: 00 \mathrm{~h}$ & $18: 00 \mathrm{~h}$ & $20: 00 \mathrm{~h}$ & $22: 00 \mathrm{~h}$ \\
\hline At opening d & 30.8 & 31.2 & 30.4 & 27.2 & 25.2 & 25.8 \\
\hline $20^{\mathrm{a}}$ & 23.6 & 25.8 & 25.4 & 29.4 & 27.6 & 26.8 \\
\hline $30^{b}$ & - & - & - & 26 & 25 & 25 \\
\hline $45^{b}$ & - & - & 23 & 24 & 25 & 25 \\
\hline \multicolumn{6}{|c|}{${ }^{\circ}$ Mean of temperatures in 5 burrows } & \\
\hline
\end{tabular}

Table 3. Uca inversa. Burrow air temperature profiles taken at Ras Hatiba on

Further field measurements at the Ras Hatiba site were made from $13: 30$ to 21:30 h on 23 March 1989. On this occasion, temperature and $\mathrm{RH}$ were measured in and around a mangrove tree utilized by Metopograpsus messor and notes made of the behaviour of unrestrained crabs. Using thermocouples, the body temperatures of 4 crabs were monitored in controlled conditions of sunlight and shade (see below). These crabs had local freedom of movement, but tethering of the thermocouple wires prevented them moving from selected conditions (e.g. they 1989. RH reached $100 \%$ in burrows at night; maximum values for the air above the sediment surface were 90 , 99 and 100\% for October, December and January observations, respectively. The drop in $\mathrm{RH}$ above the sediment surface during the day was more marked in October (to $64 \%$ ) than in December or January (to $79 \%$ in each case), but it always remained higher within the burrows (lowest values: October $74 \%$, December $88 \%$, January $94 \%$ - the probe measured $\mathrm{RH}$ at ca $20 \mathrm{~cm}$ depth within the burrow).

\section{Metopograpsus messor habitat}

During the October 1987 observations, RH measurements were also taken close to the basal part of the trunk of Avicennia marina trees and amongst the foliage, i.e in the regions often frequented by Metopograpsus messor. During the day these $\mathrm{RH}$ values were usually slightly higher (up to $5 \%$ ) than values away from the trees.

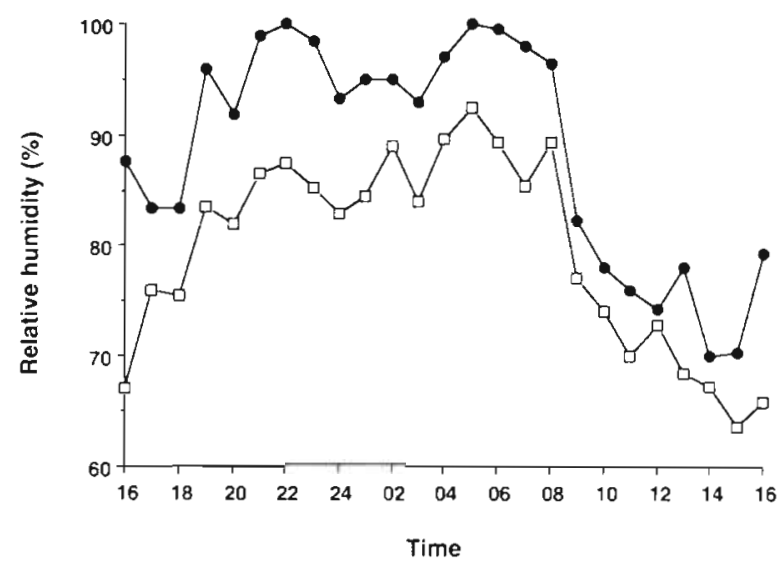

Fig. 5. Uca inversa. Diel variations in relative humidity within a crab burrow ( ) and at $2 \mathrm{~cm}$ above the sediment surface ( $\square$ ). Recordings were made at the Ras Hatiba site, concurrently with the temperature recordings shown in Fig. 3 could be kept on the sediment surface or amongst vegetation, in either shade or open sun).

During the period of observation, the temperature of the sediment surface dropped from nearly $37^{\circ} \mathrm{C}$ at $13: 30 \mathrm{~h}$ (in direct sunlight until $17: 30 \mathrm{~h}$ ) to around $21.5^{\circ} \mathrm{C}$ at $21: 30 \mathrm{~h}$ (Fig. 6). Unfortunately, the sediment surface probe became partially buried, but showed that the temperature at around $1 \mathrm{~cm}$ below the surface of shaded sediment was relatively constant throughout this period, at around $25^{\circ} \mathrm{C}$, varying by less than $2^{\circ} \mathrm{C}$. Based on the evidence of Table 1 , the temperature at the sediment surface will be several degrees warmer than this during daylight. Air temperatures just above the ground and at various heights above it adjacent to the trunk and amongst the foliage of the mangrove tree showed that temperatures here were very similar to each other and less severe than at the surface of unshaded sediment, declining from $31.4^{\circ} \mathrm{C}$ at $13: 30 \mathrm{~h}$ to $23.9^{\circ} \mathrm{C}$ at $21: 30 \mathrm{~h}$. The water temperature at the edge of the rising tide also followed a similar trend, declining from $27^{\circ} \mathrm{C}$ at $16: 00 \mathrm{~h}$ to $23^{\circ} \mathrm{C}$ at $21: 30 \mathrm{~h}$, with the water reaching the site at $21: 30 \mathrm{~h}$. Thus, the water temperature in the Avicennia marina zone was lower than in the October observations, this being due to the fact that the flat was not inundated until the evening.

Measurements of RH on 23 March showed that 2 to $3 \mathrm{~cm}$ above the sediment surface, amongst the pneumatophores of the mangroves, RH rose from $80 \%$ at $15: 30 \mathrm{~h}$ (the first measurement) to $100 \%$ following sunset. Values were lower amongst the foliage, some $1.5 \mathrm{~m}$ above the ground, increasing from $65 \%$ at $15: 30 \mathrm{~h}$ to around $75 \%$ after dusk the last reading was at $21: 30 \mathrm{~h}$ ).

Thermocouples attached to crabs were used to simultaneously measure crab body temperature and the temperature just above the dorsal carapace. Fig. 6 illustrates representative results from 2 crabs, one maintained in the sun and the other in the shade (on moist sediment in each case). The advantages of remaining in shaded conditions are clear. Crab tem- 


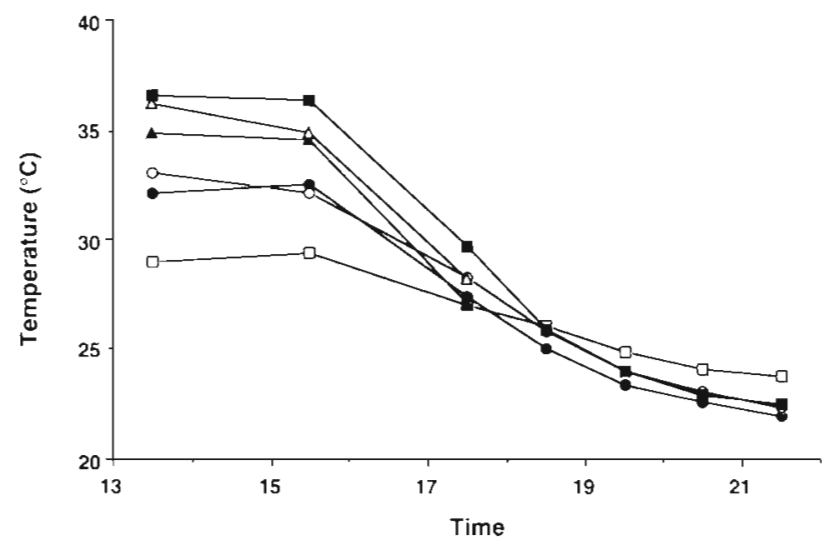

Fig. 6. Metopograpsus messor. Variations in environmental temperature and crab body temperature over 8 h at the Ras Hatiba study site on 25 March 1989. Temperature recordings are of sediment surface ( $\mathbf{a})$, air close $(\mathrm{ca} 2 \mathrm{~cm}$ ) to the sediment surface ( $\square$ ), the body temperatures of 2 individual crabs $(\bullet)$ ). and the temperature of the air in close proximity to each crab (see text) $(0, \Delta)$. One crab $(\Delta)$ experienced direct sunlight from 13:30 to $17: 30 \mathrm{~h}$, whereas the other crab (-) was maintained in the shade of an Avicennia marina tree during this period. Recordings from the first crab were discontinued at 17:30 h when it was no longer in direct sunlight

perature was intermediate between the initially unshaded sediment surface temperature and the air temperature measured by the thermocouples near the ground and amongst the vegetation. These thermocouples gave a temperature lower than those given by the air temperature thermocouple attached to each crab, but the records of crab body temperature were very similar to the temperatures recorded by the thermocouple reading air temperature just above (ca $2 \mathrm{~mm}$ ) the carapace. The most likely explanation for these air temperature differences is that, despite being in the shade provided by a mangrove tree, the dark bodied crab may have absorbed sufficient solar energy to slightly elevate its temperature relative to its surroundings during daytime.

\section{Physiological responses}

\section{Uca inversa}

It has been seen that, when the crab was within its burrow, its body temperature closely followed burrow environmental temperature (Fig. 3A, B). Both data sets show slight divergence between crab body temperature and burrow environment temperature. This could be a real effect: where the divergence occurs, the crab is usually slightly cooler than the burrow. A number of mechanisms enable crabs to keep cooler than their immediate environment (see Smith \& Miller
1973); a major one is evaporative cooling. This could only work within the burrow if the relative humidity around the crab was less than $100 \%$. Evaporative cooling may be suggested by the data illustrated in Fig $3 \mathrm{~A}$ where a very small divergence between crab body temperature and burrow environment temperature was only apparent during the day. Discounting a calibration error, a more likely explanation for the divergence in the data illustrated in Fig. $3 \mathrm{~B}$ is that small differences between air and sediment temperature are reflected in the data, depending on whether or not the thermocouple on the carapace was in air or was against the burrow wall. The differences are, in any case, very small.

In order to investigate the ability of crabs to achieve body temperatures below those of the environment, several crabs were maintained on the sediment surface in direct sunlight and in the shade. Thermocouples were used to record body temperature and air temperature just above the dorsal carapace. The temperature data illustrated in Fig, 7 show a typical result for a crab moved into direct sunlight. This crab was able to keep its body temperature lower than that of the outside air (relative humidity was $80 \%$ ). It is likely that this effect was mainly due to evaporative cooling (see Smith \& Miller 1973). Most of these experiments were carried out in simulated natural environments in outside aquaria at the Obhur Marine Station. Here crabs deprived of access to their burrows had access to shallow (ca $1 \mathrm{~cm}$ deep) pools of water which they visited frequently. One field observation is pertinent. On this occasion, a crab became trapped on the sediment surface by its thermocouple wires. The crab survived for just $1 \mathrm{~h}$ and its death was presumably caused by the combined effects of high temperature (the mud surface temperature reached $47^{\circ} \mathrm{C}$ ) and desiccation stress.

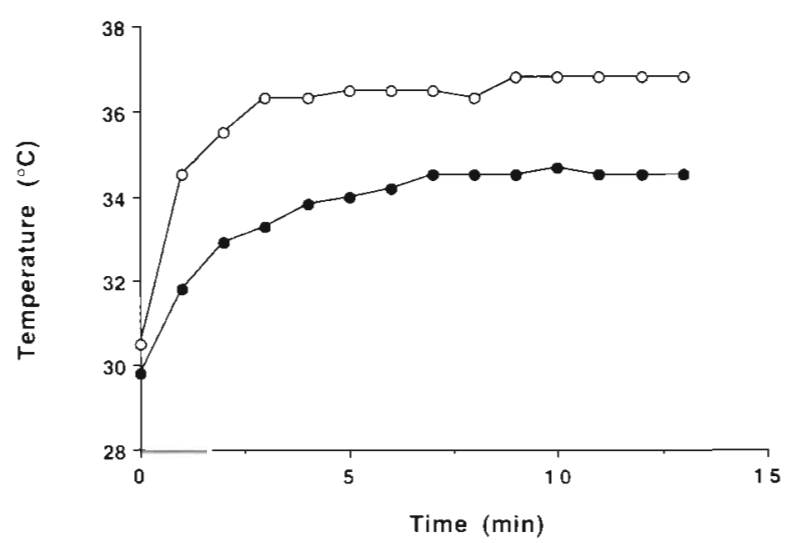

Fig. 7 Uca inversa. Recordings of crab body temperature (•) and air temperature in close proximity to the crab (o). Crab was moved from shade into full sunlight at time 0 min 
Similar lethal results of being trapped on the sediment surface away from water were seen in crabs in simulated natural conditions in outdoor aquaria. Under natural conditions, periodic visits to their burrows enabled crabs to take up water (water is essential for the floatation deposit feeding strategy as well as for gill irrigation and evaporative cooling)

The degree of physiological stress imposed by temperature changes can be assessed from an examination of corresponding changes in heart rate. Seven crabs were prepared for simultaneous recording of body temperature and heart rate and typical results are presented in Fig. 8A, B. In general terms, heart rate was positively correlated with environmental temperature. When Fig. 8A and $8 \mathrm{~B}$ are compared, a seasonal difference in the temperature range experienced by the crabs is evident, but the trends are similar. Taking into account the temperature profiles presented in Fig. 4 and Tables 1 to 3 , it should have been possible for crabs to maintain themselves in a narrower temperature range than that experienced (Fig. 8). The movement of experimental crabs within their burrows was probably impeded by trailing wires since they did not emerge during the day. Whether or not unrestrained crabs adjust their position within their burrows for thermal reasons remains unknown, but is an intriguing possibility.

Heart rates in the 7 crabs used in the field experiments varied from below 100 beats $\mathrm{min}^{-1}$ at around $20^{\circ} \mathrm{C}$ to over 300 beats $\mathrm{min}^{-1}$ at around $30^{\circ} \mathrm{C}$. Smaller crabs had higher heart rates than larger crabs, which is a normal relationship (Eshky et al. 1988). Further information on the relationships between crab size, body temperature and heart rate will be published elsewhere, together with evidence that small Uca inversa are more vulnerable to high temperatures than large specimens.

In the outdoor tanks at the Obhur Marine Station, crabs wired for heart rate recordings occasionally moved in and out of their burrows (unlike the wired crabs observed in the field). These data showed a close relationship between temperature and heart rate and between heart rate and activity. Thus, the highest heart rates were recorded from active crabs on the sediment surface in sunlight and the lowest rates from inactive crabs within their burrows at night. For example, a $1.4 \mathrm{~g}$ male crab had a heart rate of around 300 beats min $^{-1}$ when active on the sediment surface at $35^{\circ} \mathrm{C}$, and this reached 368 beats $\mathrm{min}^{-1}$ at $40^{\circ} \mathrm{C}$.
A

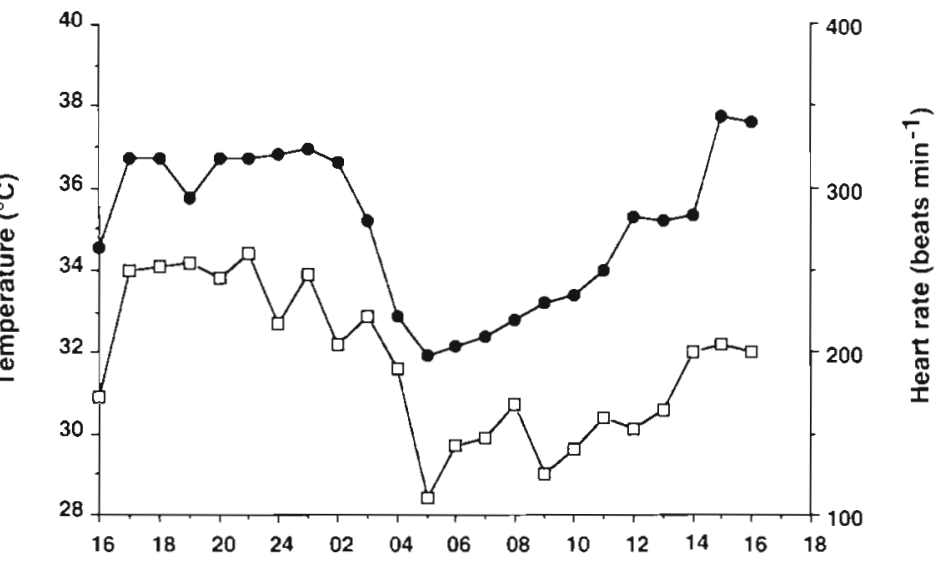

B

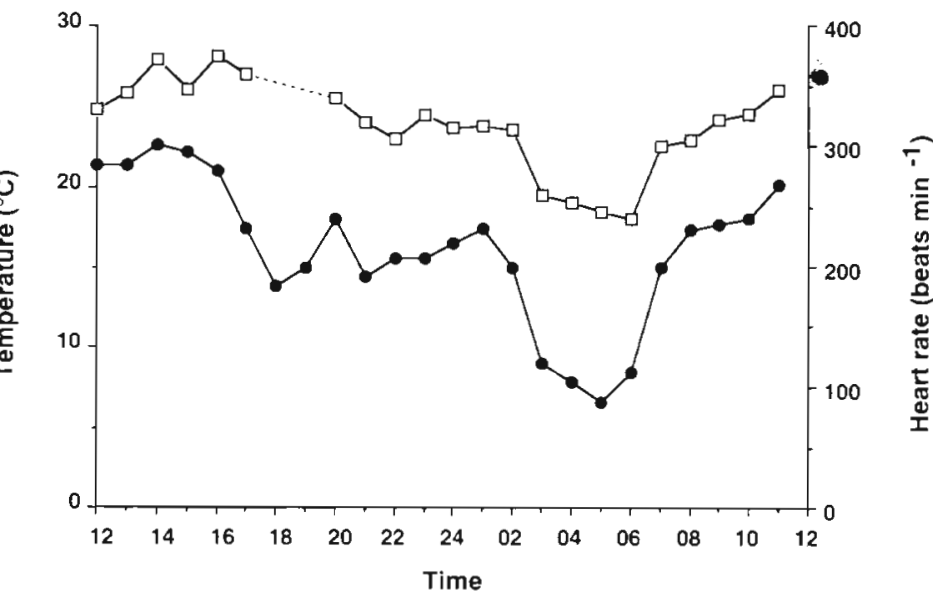

Fig. 8. Uca inversa. Field recordings of diel variations in crab body temperature ( $\square$ ) and heart rate (-) at Ras Hatiba in (A) October 1987 and (B) December 1987. Broken line in (B): recording failure. Recordings commenced at $16: 00 \mathrm{~h}$ in October, but at 12:00 $\mathrm{h}$ in December

Crab weights were $3.1 \mathrm{~g}$ and $2.2 \mathrm{~g}$ in $(\mathrm{A})$ and $(\mathrm{B})$, respectively

Heart rate dropped to around 100 beats $\mathrm{min}^{-1}$ in the burrow at night.

\section{Metopograpsus messor}

Experiments in simulated natural conditions in outdoor aquaria at the Obhur Marine Station indicated that this species is vulnerable to high temperature stress. With ready access to water, some crabs experiencing 20 min periods of exposure to sunlight were able to use evaporative cooling to achieve modest reductions in their body temperature relative to the temperature of the outside air (usually $<1^{\circ} \mathrm{C}$ ) 
throughout this period. Other crabs seemed unable to prevent rapid rises in body temperature by this means. Crabs in the simulated environment of the outside aquarium died on hot days if they were unsuccessful in securing a retreat in deep shade. The upper lethal limit was not determined, but laboratory experiments indicated that crabs in damp, shaded conditions were able to survive at $40^{\circ} \mathrm{C}$ in saturated air.

\section{DISCUSSION}

The results obtained in this study provide a partial insight into behavioural and physiological adaptations to one of the world's harshest littoral environments, where high temperatures pose a potentially lethal problem to shore fauna.

Crab temperature is influenced by a number of factors. Heat will be conducted from the surrounding sediment and air, and gained from absorbed radiant energy. A blanched carapace will reflect solar energy rather than absorb it; raising the body will reduce the influence of substratum temperature; evaporation will reduce body temperature. These and other mechanisms, e.g. orientation, are discussed by Smith \& Miller (1973). In several Uca species carapace blanching occurs in males [a display behaviour - see Crane (1975)] and this also serves to reflect radiant energy. A limited degree of carapace blanching is seen in male Uca inversa, but it is not pronounced and its effect on body temperature was not investigated. The pale major cheliped will also reflect radiant energy. In contrast, Metopograpsus messor is uniformly dark in colour and so will absorb radiant energy.

Evaporation was shown to be an effective cooling method. For Uca inversa, utilization of the burrow environment kept the temperature changes experienced by the crabs in a narrower range than those of the thermal conditions at or just above the sediment surface. Consequently, physiological stress effects were minimized. Metopograpsus messor sought shaded, damp locations amongst the mangrove roots during the day and were rarely seen in direct sunlight. M. messor were occasionally seen moving through standing water, but those observed remained immersed only for short periods. Intolerance of prolonged immersion by several species of semiterrestrial crab has received comment from a number of workers (summarized in Eshky et al. 1988), but the reason for this behaviour was not investigated in $M$. messor. It was noted, however, that water temperatures over the tidal flat were high (up to $38.5^{\circ} \mathrm{C}$ during the periods of observation). Immersed crabs may therefore have been vulnerable to both thermal and hypoxic stresses.
During the warmest part of the day, unshaded sediment surface temperatures exceeded the presumed upper lethal limits of both species of crab. Deprived of the ability to reduce their temperature by evaporative cooling, crabs trapped on the dry sediment surface died.

Metopograpsus messor, like other semiterrestrial grapsids, needs to have a film of water beneath its body in order to maintain a circulation of water between its branchial surfaces and certain external body surfaces where the water is reoxygenated (Alexander \& Ewer 1969). These authors have shown that evaporative losses prevent such circulation from being maintained when crabs do not have contact with moist substrata. Uca inversa has extensively vascularized expanded epibranchial chambers which are analogous to lungs (Verwey 1930). These are air filled, but their surfaces need to be kept moist: water is periodically replenished from either moist substrata or standing water, the main source of which is within the burrow. The presence of epibranchial 'lungs' means that $U$. inversa does not need to reoxygenate branchial water by passing it over external body surfaces, so it does not require constant access to surface water. This respiratory difference is a further explanation for the observation that $M$. messor was seen to occupy shaded, damp locations during the day.

Although the observations and experiments reported here need to be extended, they do give an insight into the way that 2 mangal decapods cope with the often dramatic fluctuations in physical environmental variables that occur in their semiterrestrial environment. For one, Uca inversa, the burrow provides refuge not only from predators, but also from environmental extremes. Without this protection, it would be impossible for this species to survive the harshness of its environment. The present work builds on that of Edney (1961) and Crane (1975) for this species. $U$. inversa experiences more extreme conditions than most crabs of this genus and occurs higher on the shore than any other Red Sea species of Uca. The importance of a burrow in providing various crab species with protection from environmental extremes has been noted by a number of workers (e.g. Edney 1961, 1962, Powers \& Cole 1976, Messana et al. 1977, Macintosh 1978, 1982, 1988); Atkinson \& Taylor (1988) review much of this information. Burrows reportedly give protection from both high and low temperature extremes. Edney (1961) indicated that the lower lethal temperature for $U$. inversa from Inhaca Island (Mozambique) was between 7 and $8.5^{\circ} \mathrm{C}$ and he considered that such temperatures would rarely, if ever, be encountered (as is also likely for Red Sea beaches). Smith \& Miller (1973) and Powers \& Cole (1976) were able to show that both upper and lower lethal temper- 
atures could be experienced by Uca spp. from Florida and Texas (USA) and the burrow provided essential protection from both. It is clear that upper and lower lethal temperatures for various $U_{C a}$ species can be correlated with their habitat temperature and that the geographical distribution of Uca species is influenced by their ability to cope with thermal extremes (Vernberg \& Tashian 1959, Edney 1961, Vernberg \& Vernberg 1967).

Burrows also give access to water. For Uca spp., a regular pattern of burrow retreat behaviour is well known (Wilkens \& Fingerman 1965), though its primary function has been debated. The primary function of this burrow retreat behaviour is not thought to be thermoregulatory [as suggested by Wilkens \& Fingerman (1965)], but to replace lost water (Smith \& Miller 1973, Macintosh 1978, Little 1983). Macintosh (1978) considered that the main stimulus for this behaviour was feeding (the separation of organic material from sediment in the mouthparts requires water; Miller 1961), rather than the replacement of evaporative losses. Macintosh $(1978,1988)$ noted that the frequency of burrow visits by Uca spp. increased above $28^{\circ} \mathrm{C}$, and he attributed this to compensation for high temperatures. Smith \& Miller (1973) indicate that body surfaces remoistened within the burrow would result in evaporative cooling when a crab returned to the surface. Crabs will not only lose water from moistened surfaces, however, since the exoskeleton is not impervious (Herreid 1969a, b). High temperature and desiccation stresses are related and it seems likely to us that water loss is also an important stimulus for retreat to the burrow. The importance of the burrow, however, is not in question. Macintosh (1988) states that the burrows of crabs in SE Asian mangroves provide essential protection from temperature and salinity stress, desiccation and predation. This must also be true for Red Sea burrowing crabs like $U$. inversa.

Metopograpsus messor lacks a habitual burrowing strategy, although some crabs were observed to use burrows as refuges, and the grapsid mainly makes strategic use of the shade provided by the mangrove vegetation in order to escape from high environmental temperatures. Since some mangrove crabs have been shown to vary their use of refuges in response tn seasonal differences in microhabitat climate (Wilson 1989), it would be interesting to further investigate the use of cover by $M$. messor

For Uca inversa, it is now necessary to precisely determine lethal limits and compare them with the results of Edney (1961) who briefly worked on the same species at Inhaca Island. Water loss needs to be evaluated at different temperatures and humidities, as does rehydration success following desiccation, so that the stress tolerance of the species can be assessed.
Such changes require information on osmoregulation, excretion and blood chemistry. Evaporative cooling not only involves water loss, but also the concentration of salts. There is a delicate balance to be achieved between evaporative cooling strategies and water and salt regulation (see Bliss 1968, Little 1983, Powers \& Bliss 1983). All these aspects will need to be assessed before a comprehensive view of adaptation to environment can be formulated.

It must be remembered that the behavioural and physiological responses reported above relate to only short periods of field work. They need to be compared with field results at other tidal periods and at other times of year. For example, little burrowing activity was observed in Uca inversa. Was this because burrowing mainly occurs during periods of spring tide? How does the severity of the microclimate during spring tides compare with those during neap tides? Does environmental high temperature modify $U$. inversa behaviour during summer? What happens to the seemingly vulnerable Metopograpsus messor in summer? What is the physiological response of each species to low temperature? There are many such questions that further work may resolve.

Acknowledgements. We are grateful to Prof. A. K. Khafagi and colleagues at the Faculty of Marine Science, King Abdulaziz University, Jeddah, for ther friendship and encouragement. We also gratefully acknowledge the assistance of Dr S. Oakley and $\mathrm{Mr} \mathrm{N}$. Pilcher The work was funded by a research grant from King Abdulaziz University.

\section{LITERATURE CITED}

Alexander SJ, Ewer DW (1969) A comparative study of some aspects of the biology of Sesarma catenata Ort. and Cyclograpsus punctatus $\mathrm{M}$. Edw. with additional observations on Sesarma meinerti De Man. Zool Afr 4:1-35

Atkinson RJA, Taylor AC (1988) Physiological ecology of burrowing decapods. In: Fincham AA, Rainbow PS (eds) Aspects of decapod crustacean biology. Symp Zool Soc Lond 59:201-226

Banerjee SK (1960) Biological results of the Snellius Expedition. XVIII. The genera Grapsus, Geograpsus and Metopograpsus (Crustacea Brachyura). Temnickia 10:132-199

Barnard KH (1950) Descriptive catalogue of South African decapod Crustacea. Ann S Afr Mus 38:1.-837

Bliss DE (1968) Transition from water to land in decapod crustaceans. Am Zool 8:355-392

Crane J (1975) Fiddler crabs of the world. Ocypodidae: genus Uca. Princeton University Press, Princeton

Crosnier A (1965) Crustacés décapodes. Grapsidae et Ocypodıdae. Fauna Madagascar 18:1-143

Edney EB (1961) The water and heat relationships of fiddler crabs (Uca spp.). Trans R Soc S Afr 36:71-91

Edney EB (1962) Some aspects of temperature relationshups in fiddler crabs (Uca spp.). In: Tromp SW (ed) Brometeorology. Pergamon Press, Oxford, p 79-85

Eshky AA (1985) Aspects of the ecology, behaviour and physiology of the ghost crab Ocypode saratan (Forskâl). PhD thesis, University of Glasgow 
Eshky AA, Atkinson RJA, Taylor AC (1988) Effects of temperature on oxygen consumption and heart rate in the semiterrestrial crab, Ocypode saratan (Forskål). Mar Behav Physiol 13:341-358

Fishelson L (1971) Ecology and distribution of benthic fauna in the shallow waters of the Red Sea. Mar Biol 10: $113-133$

Forest J, Guinot D (1961) Crustacés décapodes brachyoures de Tahiti et des Taumoto. In: Expédition française sur les récifs coralliens de la Nouvelle Calédonie. Volume préliminaire. Editions de la Fondation Singer-Polignac, Paris, p 1-195

Hartnoll RG (1975) The Grapsidae and Ocypodidae (Decapoda: Brachyura) of Tanzania. J Zool, Lond 177:305-328

Herreid CF (1969a) Water loss of crabs from different habitats. Comp Biochem Physiol 28:829-839

Herreid CF (1969b) Integument permeability of crabs and adaptation to land. Comp Biochem Physiol 29:423-429

Hoggarth KR, Trueman ER (1967) Techniques for recording the activity of aquatic invertebrates. Nature 213:1050-1051

Jones DA, Ghamrawy M, Wahbeh MI (1987) Littoral and shallow subtidal environments. In: Edwards AJ, Head SM (eds) Key environments - Red Sea. Pergamon Press, Oxford, p 169-193

Lehmann U (1976) Interpretation of entrained and free-running locomotor activity patterns of Uca. In: de Coursey PL (ed) Biological rhythms in the marine environment. Belle W Baruch Library in Marine Science, No. 4. South Carolina Press, Columbia, p 77-91

Lewinsohn C (1977) Die Ocypodidae des Roten Meeres (Crustacea Decapoda, Brachyura). Zool Verh 152:45-84

Little C (1983) The colonization of land. Origins and adaptations of terrestrial animals. Cambridge University Press, Cambridge

Macintosh DJ (1978) Some responses of tropical mangrove fiddler crabs (Uca spp.) to high environmental temperatures. In: McLusky DS, Berry AJ (eds) Physiology and behaviour of marine organisms. 12th Eur Mar Biol Symp. Pergamon Press, Oxford, p 49-56

Macintosh DJ (1982) Ecological comparisons of mangrove swamp and salt marsh fiddler crabs. In: Gopal B, Wetzel RE, Turner RE, Whigham DF (eds) Wetlands. Ecology and management. National Institute of Ecology and International Scientific Publications, Jaipur, p 243-257

Macintosh DJ (1988) The ecology and physiology of decapods of mangrove swamps. In: Fincham AA, Rainbow PS (eds) Aspects of decapod crustacean biology. Symp Zool Soc Lond 59:315-341

Macnae W (1968) A general account of the fauna and flora of mangrove swamps and forests in the Indo-west-Pacific region. Adv mar Biol 6:73-270

Messana G, Chelazzi G, Chelazzi L, Ercolini A, Ferrara F, Messeri P, Pardi L, Vannini M (1977) Researches on the coast of Somalia. The shore and dune of San Uanle. 12. Physical environment: microclimate and soil. Monit zool ital (NS) 9:147-181

This article was presented by D.S. McLusky (Senior Editorial Advisor), Stirling, UK
Micheli F, Gherardi F, Vannini M (1991) Feeding and burrowing ecology of 2 East African mangrove crabs. Mar Biol $111: 247-254$

Miller DC (1961) The feeding mechanism of fiddler crabs, with ecological considerations of feeding adaptations. Zoologica, NY 46:89-100

Morley NJF (1975) The coastal waters of the Red Sea. Bull mar Res Centre Saudi Arabia 5:1-19

Powers LW, Bliss DE (1983) Terrestrial adaptations. In: Vernberg FJ, Vernberg WB (eds) The biology of Crustacea, Vol 8. Environmental adaptations. Academic Press, New York, p 271-333

Powers LW, Cole JF (1976) Temperature variation in fiddler crab microhabitats. J exp mar Biol Ecol 21:141-157

Sheppard C. Price A, Roberts C (1992) Marine ecology of the Arabian region. Academic Press, London

Smith WK, Miller PC (1973) The thermal ecology of two South Florida fiddler crabs: Uca rapax Smith and U. pugilator Bosc. Physiol Zool 46:186-207

Taylor AC (1976) The respiratory responses of Carcinus maenas to declining oxygen tension. J exp Biol 65:309-322

Vannini M. Valmori P (1981a) Researches on the coast of Somalia. The shore and the dune of Sar Uanle. 30. Grapsidae (Decapoda Brachyura). Monit zool ital (NS) 14: $57-101$

Vannini M, Valmori P (1981b) Researches on the coast of Somalia. The shore and the dune of Sar Uanle. 31. Ocypodidae and Gecarcinidae (Decapoda Brachyura). Monit zool ital (NS) 14:199-226

Vernberg FJ, Tashian RE (1959) Studies on the physiological variation between tropical and temperate zone fiddler crabs of the genus Uca. I. Thermal death limits. Ecology 40:589-593

Vernberg FJ, Vernberg WB (1967) Thermal lethal limits of southern hemisphere Uca crabs. Studies on the physiological variation between tropical and temperate zone fiddler crabs of the genus UCa. IX. Oikos 18:118-123

Verwey J (1930) Einiges über die Biologie Ost-Indischer Mangrovekrabben. Treubia 12:167-261 + PI VI-XIV

Webb HM (1983) Persistent rhythms of decapod crustaceans In: Rebach $\mathrm{S}$, Dunham DW (eds) Studies in adaptation The behaviour of higher Crustacea. John Wiley \& Sons, New York, p 197-216

Wilkens JL, Fingerman M (1965) Heat tolerance and the temperature relationships of the fiddler crab, Uca pugilator, with reference to body coloration. Biol Bull mar biol Lab Woods Hole 128:133-141

Wilson KA (1989) Ecology of mangrove crabs: predation, physical factors and refuges. Bull mar Sci 44:263-273

Zucker N (1974) Shelter bulding as a means of reducing territory size in the fiddler crab, Uca terpsichores (Crustacea: Ocypodidae). Am Midl Nat 91:224-236

Zucker N (1983) Courtship variation in the neo-tropical fiddler crab Uca deichmanni: another example of female incitation to male competition? Mar Behav Physiol 10: $57-79$

Manuscript first received: January 26, 1995

Revised version accepted: April 18, 1995 